\title{
. \\ The Opportunistic Pathogen Chryseobacterium balustinum WLT: Pathogenicity and Antibiotic Resistance
}

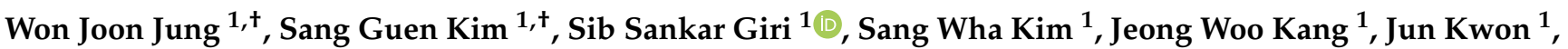 \\ Woo Taek Oh ${ }^{1}$, Sung Bin Lee ${ }^{1}$, Young Min Lee ${ }^{1}$, Su Jin Jo ${ }^{1}$, Cheng Chi ${ }^{2}$, Jin Woo Jun ${ }^{3, *}$ and Se Chang Park $1, * \mathbb{C}$
}

1 Laboratory of Aquatic Biomedicine, Research Institute for Veterinary Science, College of Veterinary Medicine, Seoul National University, Seoul 08826, Korea; cwj0125@snu.ac.kr (W.J.J.); imagine0518@snu.ac.kr (S.G.K.); ssgiri@snu.ac.kr (S.S.G.); blackcat9201@snu.ac.kr (S.W.K.); kck90@snu.ac.kr (J.W.K.); kjun1002@snu.ac.kr (J.K.); mike0202@snu.ac.kr (W.T.O.); lsbin1129@snu.ac.kr (S.B.L.); mushhama@snu.ac.kr (Y.M.L.); ssjjone@snu.ac.kr (S.J.J.)

2 Laboratory of Aquatic Nutrition and Ecology, College of Animal Science and Technology, Nanjing Agricultural University, Nanjing 210095, China; chicheng0421@snu.ac.kr

3 Department of Aquaculture, Korea National College of Agriculture and Fisheries, Jeonju 54874, Korea

* Correspondence: advancewoo@snu.ac.kr (J.W.J.); parksec@snu.ac.kr (S.C.P.)

+ These authors contributed equally to this work.

check for updates

Citation: Jung, W.J.; Kim, S.G.; Giri, S.S.; Kim, S.W.; Kang, J.W.; Kwon, J.; Oh, W.T.; Lee, S.B.; Lee, Y.M.; Jo, S.J.; et al. The Opportunistic Pathogen Chryseobacterium balustinum WLT: Pathogenicity and Antibiotic Resistance. Fishes 2022, 7, 26. https://doi.org/10.3390/ fishes7010026

Academic Editor: Lingling Wang

Received: 13 December 2021

Accepted: 19 January 2022

Published: 23 January 2022

Publisher's Note: MDPI stays neutral with regard to jurisdictional claims in published maps and institutional affiliations.

Copyright: (C) 2022 by the authors. Licensee MDPI, Basel, Switzerland. This article is an open access article distributed under the terms and conditions of the Creative Commons Attribution (CC BY) license (https:// creativecommons.org/licenses/by/ $4.0 /)$.

\begin{abstract}
This study aimed to re-evaluate the pathogenic characteristics of Chryseobacterium balustinum, generally known as a food spoilage bacterium. We observed mass mortality in a rainbow trout farm in Jeonbuk province, Republic of Korea. Fewer studies have reported on rainbow trout mortality or infections in Korea than in other countries; among these, few studies have reported cases of Chryseobacterium infections. Sequencing analysis revealed that this bacterium is closely related (99.24\%) to Chryseobacterium balustinum. Bacterial identification assays, including the API test, sequencing, and phylogenetic analysis, found the 24 isolates to be $C$. balustinum. The strain showed multiple resistance to 18 of 25 antibiotics tested. Primary clinical symptoms of its infection are damage to the fins, necrosis, and cytoplasmic vacuolation in hepatocytes. The pathogenicity of the strain was determined following Koch's postulates and the challenge test. The present results suggest that $C$. balustinum WLT can be considered a multidrug-resistant zoonotic pathogen responsible for mortality and economic losses.
\end{abstract}

Keywords: Chryseobacterium balustinum; drug-resistant; rainbow trout; Korea; pathogenicity

\section{Introduction}

Genus Chryseobacterium was first proposed by Vandamme et al. [1]. The genus was moved from the family Flavobateriaceae to the family Weeksellaceae in 2019 [2]. Chryseobacterium spp. are generally present in the environment and are found in soil, water, and lake sediments, similar to their close relatives in Flavobacteriaceae [3,4]. Chryseobacterium balustinum was first isolated from halibut that was unfit for sale because of discoloration and the softening of skin and muscle tissue [5]. Until recently, the bacterium was considered as a dairy and seafood food spoilage organism [5,6]. Similar to Flavobacterium spp., some strains of Chryseobacterium spp. are pathogenic to plants and fungi, and they are present in food products such as cow milk and raw meat [7-9].

Recently, there have been emerging reports regarding clinical cases caused by Chryseobacterium spp. in different farmed animals, such as pond loach, yellow perch, and salmonid fish, and pets such as bullfrogs and ball pythons. Chryseobacterium spp. has not been considered as a common zoonotic pathogen; only a few studies have reported clinical infections in humans $[10,11]$. Despite the general belief that Chryseobacterium is an opportunistic pathogen that only causes secondary infection in immunocompromised patients, it has been reported to cause severe sepsis in an immunocompetent traveler [12]. 
Thus, the zoonotic possibilities of the Chryseobacterium should not be neglected as we may be in close contact with it in daily life.

Due to their relatively low pathogenicity, Chryseobacterium species have been kept out of the spotlight. However, the high antibiotic resistance profiles of Chryseobacterium have been sufficient to collect general interest in perspectives of clinical relevance. They have shown resistance to antibiotics approved for industrial purposes and last-resort antibiotics, and there have been increasing reports of infections in animals in South Korea. There are not many antibiotics to use among permitted drugs. Thus, it is of utmost importance to report every Chryseobacterium outbreak to trace the dissemination in aquaculture. The antimicrobial resistance and pathogenicity of the species must be studied to select suitable antimicrobial agents as a treatment. Many studies highlight the antimicrobial resistance of the Chryseobacterium species and warn of its zoonotic possibilities [13,14].

In this study, we investigated cases of infection with Chryseobacterium in rainbow trout (Oncorhynchus mykiss) from a farm in Jeonbuk province, Republic of Korea. Identification of the bacterial isolate was confirmed through sequencing and phylogenetic analysis of the 16S rRNA gene. The antibiotic susceptibility of the bacterial isolate and the pathogenicity were assessed. Moreover, histopathological changes in the liver of diseased fish were evaluated.

\section{Materials and Methods}

\subsection{Fish Sampling}

In March 2019, a rainbow trout farm in Jeonbuk province, Republic of Korea, requested a pathological diagnosis of trout based on common clinical symptoms displayed, which included anorexia and damaged dorsal and caudal fins (Figure 1). The farm has a closed circulating water system from groundwater and the water temperature was $15-16{ }^{\circ} \mathrm{C}$. The farm reared 30,000 fish, distributed in six water tanks which contained $5000 \mathrm{~L}$ of water each. The estimated mortality rate was approximately $10 \%$; however, continuous and visible clinical symptoms gradually intensified. The percentage of affected fish was $>80 \%$ and the size of the fish was approximately $1 \mathrm{~kg} \pm 100 \mathrm{~g}$. Infected fish experienced common symptoms including loss of appetite and hemorrhage in the caudal fin. Ten fish with severe clinical symptoms were selected for the study. They were caught and transported to the Laboratory of Aquatic Biomedicine at Seoul National University, Seoul. These fish were inspected for any external lesions visually and microscopically for bacterial, viral, and parasitic diseases. The gills and fins of the fish were swabbed and smeared on glass slide for observation under a light microscope. Viral infection, infectious hematopoietic necrosis virus (IHNV), infectious pancreatic necrosis virus (IPNV), and viral hemorrhagic septicemia virus (VHSV) were diagnosed using PCR and specific primers. Thereafter, the kidney, liver, and spleen were dissected for bacterial isolation.

\subsection{Bacterial Isolation}

The recovery of bacteria was performed from the liver, kidney, and spleen of rainbow trout. Each tissue sample was streaked directly on tryptic soy agar (BD Difco, Detroit, MI, USA) and cytophaga agar. Streaked plates were incubated at $20^{\circ} \mathrm{C}$ and $25{ }^{\circ} \mathrm{C}$ for $72 \mathrm{~h}$ and bacterial growth was monitored. Colonies present in the largest proportion were sub-cultured. Recovered bacteria were stored at $-80^{\circ} \mathrm{C}$ in tryptic soy broth (BD Difco, Detroit, MI, USA) supplemented with $25 \%$ glycerol for further analysis.

\subsection{Biochemical Characterization}

The Gram reaction of bacterial isolates was determined using a Gram staining kit (BioMerieux, Seoul, Korea) following the manufacturer's protocols. The oxidase reaction and catalase activity were assayed using 1\% tetramethyl-p-phenylenediamine (Merck, Madison, NJ, USA) and 3\% (volume by volume) aqueous hydrogen peroxide solution, respectively. For bacterial identification, API 20NE and API ZYM kits (BioMerieux, Seoul, Korea) were used following the manufacturer's protocols. 

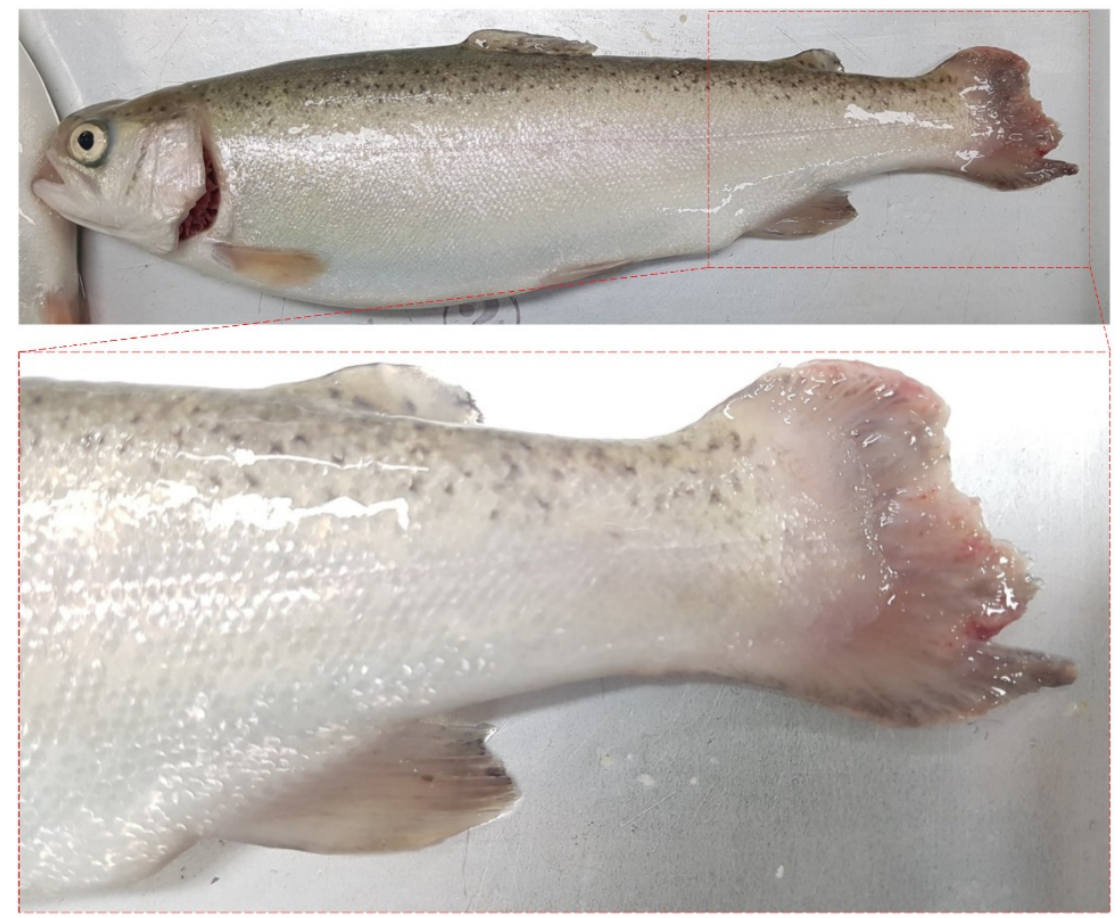

Figure 1. Clinical symptoms of Chryseobacterium balustinum infection indicate severe damage on the dorsal and caudal fin.

\subsection{Bacterial Identification}

Sub-cultured bacteria were grown on TSA at $25^{\circ} \mathrm{C}$ for $24 \mathrm{~h}$ and the bacterial DNA was extracted using a Qiagen DNeasy Tissue Kit (Qiagen Sciences, Valencia, CA, USA) for $16 S$ rRNA gene analysis using PCR. For PCR amplification, universal primers (27F, 1492R) targeting $16 \mathrm{~S}$ rRNA gene were used, as previously reported [15]. PCR products were sent to the genomics division of Macrogen (Seoul, Korea) for gene sequence analysis, where nucleotide sequencing was performed using ABI PRISM 3730XL Analyzer with BigDye ${ }^{\circledR}$ Terminator v3.1 Cycle Sequencing Kits (Applied Biosystems, Waltham, MA, USA).

\subsection{Phylogenetic Analysis}

As all the 16S rRNA genes of the isolates were $100 \%$ identical, the sequence of strain WLT was included in the phylogenetic analysis as a representative. The 16S rRNA gene sequence was used to assess the similarity with other Chryseobacterium spp., using BLASTn (NCBI, Bethesda, MD, USA) and EzBioCloud server (https://www.ezbiocloud.net/) to identify similar bacterial strains. Twenty closely related bacteria of the genus Chryseobacterium were selected for phylogenetic analysis and sequences were aligned using MEGA X software [16]. The 16S rRNA sequence of Janthinobacterium tructae SNU WT3 was included as an out-group [17]. A phylogenetic tree was constructed using the MEGA X software using the neighbor-joining method, and evolutionary distances were calculated using Kimura's 2-parameter model [18,19]. Tree topology was assessed using 1000 bootstrap replicates [20]. The 16S rRNA gene sequence of the Chryseobacterium WLT was deposited within GenBank (Accession number: MN317337).

\subsection{Histopathological Analysis}

Fish displaying severe clinical signs, including damaged fins and lethargic behavior, were selected for histopathological examination. The spleen, kidney, and liver were dissected and preserved in 10\% neutral-buffered formalin to determine the pathological and degenerative changes resulting from the infection. Fixed tissues were trimmed, dehydrated using ethanol, embedded in paraffin blocks, and sectioned and stained with hematoxylin 
and eosin. The specimens were examined using a light microscope and digitally scanned by Xenos Inc. (Seoul, Korea).

\subsection{Antibiotic Susceptibility Test}

The bacterial strain isolated from diseased rainbow trout was subjected to antibiotic susceptibility tests against 24 antibiotics using the disk diffusion method on Mueller-Hinton agar (BD Difco, Detroit, MI, USA). Chryseobacterium spp. is inherently resistant to various antibiotics including tetracycline, erythromycin, linezolid, aminoglycosides, chloramphenicol, and beta-lactams. The following antibiotics were assayed: amikacin, ampicillin, piperacillin, cefazolin, cefepime, cefotaxime, cefoxitin, ceftazidime, ceftizoxime, aztreonam, imipenem, meropenem, gentamicin, kanamycin, streptomycin, tetracycline, doxycycline, ciprofloxacin, nalidixic acid, norfloxacin, ofloxacin, trimethoprim-sulfamethoxazole, chloramphenicol, and erythromycin. The results were determined as resistant, intermediate, and susceptible, and were assessed based on the diameter of the zone of inhibition $(\mathrm{mm})$ [21].

\subsection{Pathogenicity Challenge Trials}

To estimate the pathogenicity of bacterial isolates, rainbow trout weighing $20 \mathrm{~g}$ on average were purchased from another farm in Chungbuk province, Republic of Korea. Fish were transported and stabilized for two weeks before the trial under the same conditions as the challenge trial. Thirty fish were intraperitoneally injected with $3 \times 10^{7}, 10^{6}, 10^{5}$, and $10^{4} \mathrm{CFU}$ of bacteria per fish in each group. The control groups were injected with the same volume of PBS. The experiments were performed with 30 fish per group, and the average mortality rates were determined as days post infection. Each group of artificially infected fish was kept in $120 \mathrm{~L}$ water tanks, and the water temperature was regulated at $16{ }^{\circ} \mathrm{C}$. The trials were conducted for $15 \mathrm{~d}$ after all fish groups were stabilized.

\section{Results}

\subsection{Clinical Symptoms and Bacterial Isolation}

The clinical symptoms observed herein, such as severe damage to the caudal fin in diseased fish, were similar to that of cases of Flavobacterium psychrophilum infection [22]. However, PCR-based bacterial detection yielded negative results [23]. Furthermore, no virus or parasitic infections were observed upon microscopic and macroscopic examination. Virus detection using PCR with specific primers found all samples were negative for IHNV, IPNV, and VHSV [24,25]. Moreover, since Pseudomonas fluorescens and Aeromonas salmonicida are considered major pathogens in salmonids, their detection was carried out and the results were negative [23,26-28]. After excluding some major rainbow trout pathogens, bacterial isolation was performed to identify the disease etiology. After incubation at $25^{\circ} \mathrm{C}$ for $24 \mathrm{~h}$, circular, yellow colonies of $34 \mathrm{~mm}$ diameter appeared on both TSA and cytophaga. For the isolation of pure colonies, colonies were individually sub-cultured. Notable differences between these bacteria and other Flavobacterium spp. were that culture duration was relatively short and bacterial alternation was not observed during sub-culturing [29]. Finally, a total of 24 isolates were recovered.

\subsection{Biochemical Characterization}

The strain was Gram-negative and oxidase- and catalase-positive. It did not produce indole nor reduce nitrate. With the API ZYM strip, the strain was negative for C4 esterase and $\beta$-glucosidase, but positive for $\mathrm{C} 8$ esterase lipid, valine arylamidase, trypsin, $\alpha$-glucosidase, and N-acetyl- $\beta$-glucosaminidase. On the API 20NE strip, the strain was negative for arabinose, mannitol, and citrate but positive for maltose assimilation.

\subsection{Phylogenetic Analysis}

16S rRNA gene sequencing analysis revealed 98 99\% similarity to other Chryseobacterium related species: 99.24\% (C. balustinum DSM 16775T), 98.96\% (C. piscium LMG23089T), and $98.75 \%$ (C. scophthalmum DSM 16779T). The phylogenetic tree (Figure 2) was con- 
structed with 20 Chryseobacterium spp., indicating that the Chryseobacterium spp. isolated from the rainbow trout part of this study are the causative agents of mortality and can be considered C. balustinum bacteria.

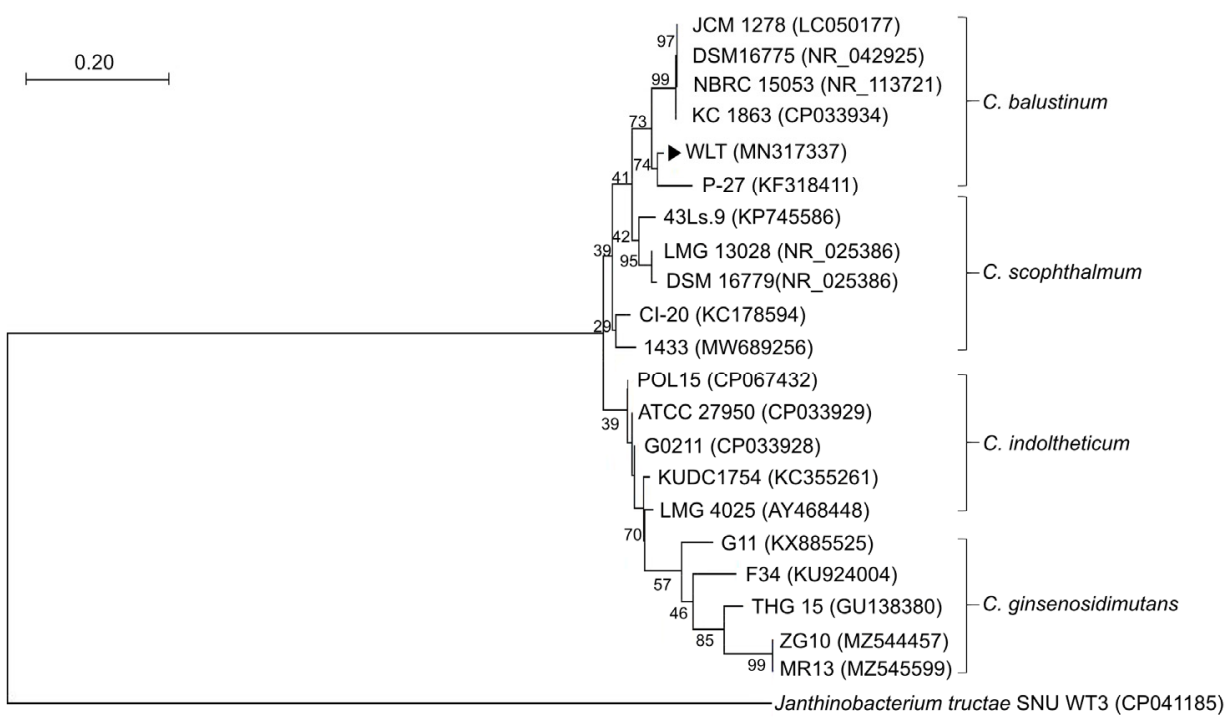

Figure 2. Phylogenetic tree constructed using 16S rRNA gene sequences of the 20 Chryseobacterium species and strain isolated in this study. The tree was constructed by MEGA X using the neighborjoining method with a bootstrap analysis of 1000 replicates. (Genbank accession number: MN317337).

\subsection{Pathogenicity Challenge Trials}

The virulence of the strain WLT was determined by the challenge trial. The first mortalities occurred within 4 days of injection, and the $3 \times 10^{7}$ group showed $60 \%$ mortality (Figure 3). The pathogenicity trial revealed that the LD50 was estimated to be lower than that of other Chryseobacterium spp. One of the Chryseobacterium spp. isolated from multiple Great Lake salmonids (T28) had an LD50 of $>10^{8}$ CFU per fish; however, the estimated LD50 value of the present isolate was between $10^{7}$ and $10^{6} \mathrm{CFU}$ per fish [30].

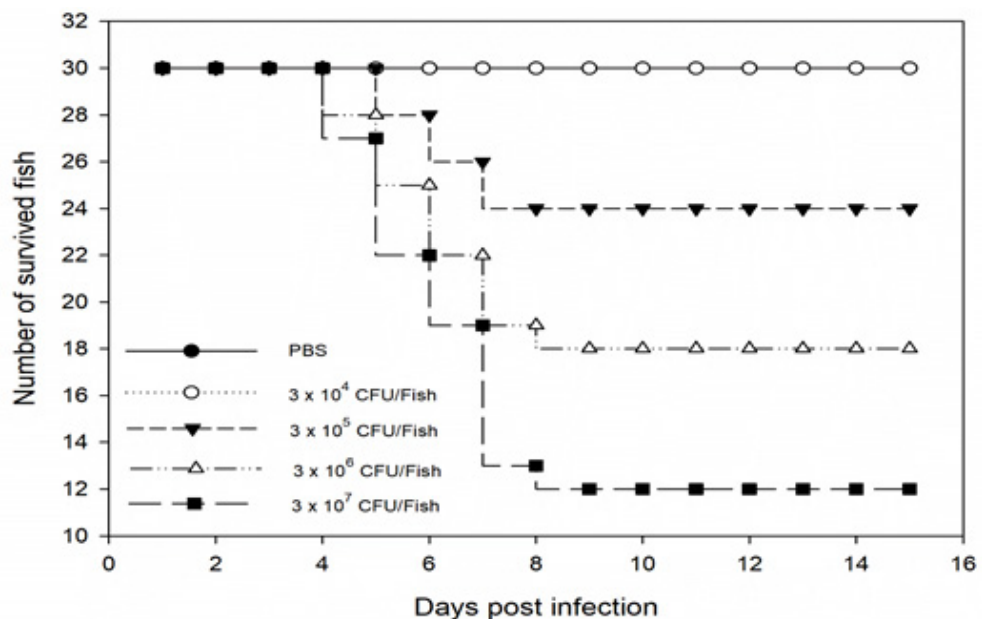

Figure 3. Challenge trial result showing the survival rate of the infected fish upon day post-infection.

\subsection{Histopathological Analysis}

Histopathological analysis revealed that the pathological lesions were more concentrated on the liver than on the kidney and spleen. Moderate hepatocyte degeneration and cytoplasmic vacuolation were observed throughout the liver (Figure 4). However, the degree of the damage was not proportional to the mortality rate of rainbow trout. In the present case, the kidney and the spleen were relatively normal. 


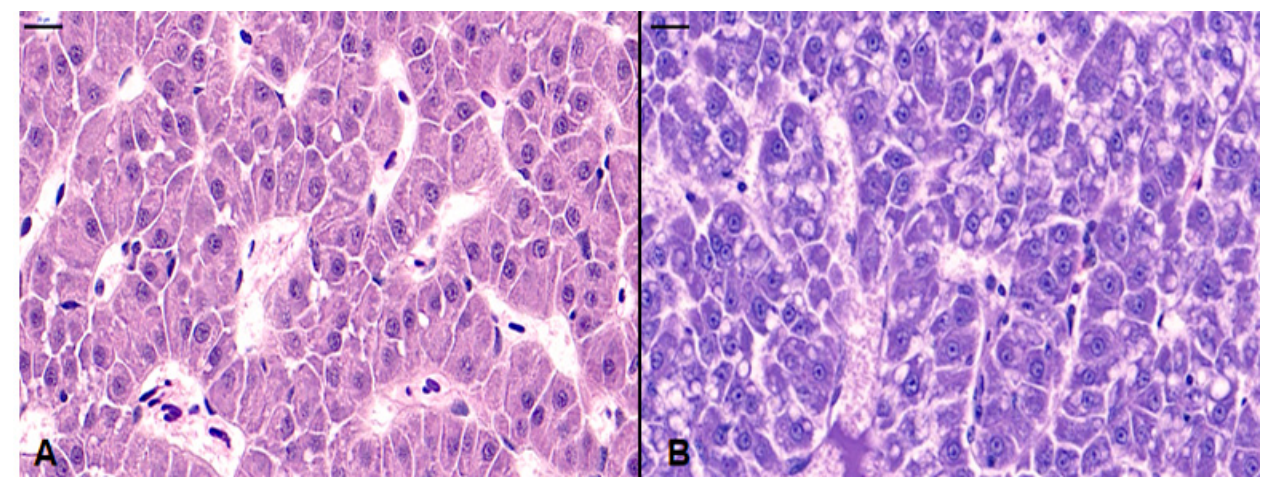

Figure 4. Histopathology of liver of healthy rainbow trout (A) and a moribund rainbow trout with Chryseobacterium balustinum WLT infection (B). Necrosis and cytoplasmic vacuolation can be observed in hepatic cells on liver of diseased fish. Slides were stained with hematoxylin and eosin. Scale bars $=20 \mu \mathrm{m}$.

\subsection{Antibiotic Susceptibility Test}

The antibiotic susceptibility test indicated that, similar to other Chryseobacterium spp., the isolate WLT was resistant to different antibiotics (Table 1). Chryseobacterium sp. is inherently resistant to numerous antibiotics including tetracyclines, erythromycin, linezolid, polymyxins, and chloramphenicol [31]. The antibiotic susceptibility test revealed that the strain was resistant to ampicillin, piperacillin, cefazolin, cefepime, cefotaxime, ceftazidime, ceftizoxime, aztreonam, gentamicin, amikacin, kanamycin, streptomycin, tetracycline, doxycycline, nalidixic acid, trimethoprim-sulfamethoxazole, chloramphenicol, and erythromycin. However, it was susceptible to cefoxitin, imipenem, meropenem, ciprofloxacin, norfloxacin, and ofloxacin.

Table 1. Antibiotic susceptibility test performed on C. balustinum WLT by disk diffusion method (R: resistant, S: susceptible, I: intermediate).

\begin{tabular}{|c|c|c|c|c|c|}
\hline Antibiotics & Susceptibility & $\begin{array}{l}\text { Inhibition Zone } \\
\text { Diameter (mm) }\end{array}$ & Antibiotics & Susceptibility & $\begin{array}{l}\text { Inhibition Zone } \\
\text { Diameter (mm) }\end{array}$ \\
\hline Ampicillin & $\mathrm{R}$ & 7 & Piperacillin & $\mathrm{R}$ & 9 \\
\hline Cefazolin & $\mathrm{R}$ & 10 & Cefepime & $\mathrm{R}$ & 9 \\
\hline Cefotaxime & $\mathrm{R}$ & 10 & Cefoxitin & $S$ & 22 \\
\hline Ceftazidime & $\mathrm{R}$ & 12 & Ceftizoxime & $\mathrm{R}$ & 3 \\
\hline Aztreonam & $\mathrm{R}$ & 2 & Imipenem & $S$ & 26 \\
\hline Meropenem & $S$ & 28 & Gentamicin & $\mathrm{R}$ & 11 \\
\hline Amikacin & $\mathrm{R}$ & 4 & Kanamycin & $\mathrm{R}$ & 5 \\
\hline Streptomycin & $\mathrm{R}$ & 2 & Tetracycline & $\mathrm{R}$ & 8 \\
\hline Doxycycline & $\mathrm{R}$ & 11 & Ciprofloxacin & S & 24 \\
\hline Nalidixic acid & $\mathrm{R}$ & 7 & Norfloxacin & $S$ & 27 \\
\hline $\begin{array}{l}\text { Trimethoprim- } \\
\text { sulfamethoxazole }\end{array}$ & $\mathrm{R}$ & 9 & Ofloxacin & $S$ & 25 \\
\hline Chloramphenicol & $\mathrm{R}$ & 13 & Erythromycin & $\mathrm{R}$ & 4 \\
\hline
\end{tabular}

\section{Discussion}

There is a tendency that Chryseobacterium spp. is often neglected in clinical settings because of the low number of cases and decreased pathogenicity. However, severe antibiotic resistance makes them hard to control, especially in immunocompromised patients or stressed animals, and this has been the case for C. balustinum. The first isolation was reported in halibut and was recognized as a food spoilage bacterium rather than a pathogenic bacterium since it was isolated from the fin of the fish $[5,6,30]$. In this study, we observed the mortality of farmed rainbow trout and verified that it originated from the infection by C. balustinum designated as WLT. 
As Chryseobacterium is prevalent in the natural environment, which includes river water and soil, there is a high possibility for individuals to be exposed to it. Indeed, a severe sepsis case was reported from those who had previous exposure to soil and water [12]. The causative agent was presumed to have infected the individuals through the skin. In the case of the present study, the pathogenesis of Chryseobacterium was presumed to proceed from a localized to a systemic infection. It was also observed in our previous report with C. cucumeris [32]. Furthermore, considering the production of proteolytic enzymes, including esterase, the zoonotic potential of C. balustinum through infection through the skin should not be excluded.

Generally, the pathogenicity of Chryseobacterium in farmed fish is comparably lower than the major bacterial pathogens (e.g., Flavobacterium and Lactococcus) and earlier studies reported $5 \mathrm{LogCFU} /$ fish as the median lethal dose of Chryseobacterium [33,34]. The LD50 of C. cucumeris in pond loach was 7.8 LogCFU/fish [32], whereas the LD50 of C. indologenes in yellow perch was 8.1 LogCFU/fish [35]. The C. scophthalmum TPBLGL 18 infection in golden mahseer resulted in median lethal dose of 6.2 LogCFU/fish [36]. Although the pathogenicity of the Chryseobacterium was not much greater than the common pathogens, multidrug-resistant features of the strain WLT may pose a therapeutic challenge $[33,34]$. Therefore, Chryseobacterium could be considered as a fish pathogenic microoganism in addition to its food spoilage activity.

Since, Chryseobacterium sp. has been recognized as an emerging fish pathogen in South Korea in recent times, studies regarding antibiotic susceptibility-based treatment methods should precede [32,37]. In a previous Chryseobacterium infection case study, we failed to cure the diseased fish and we speculated that high prevalence of antibiotic resistance by Chryseobacterium was a reason. The C. balustinum WLT also revealed resistance to almost all the tested antibiotics (e.g., ampicillin, doxycycline, and nalidixic acid against Gramnegative bacteria) that are permitted by the National Institute of Fisheries Science, South Korea for aquaculture uses. Accordingly, an effective treatment protocol should be adopted to address the emerging Chryseobacterium outbreaks.

\section{Conclusions}

In conclusion, one of the isolates of Chryseobacterium spp. pathogenic to rainbow trout closely resembled C. balustinum on 16S rRNA gene sequencing analysis. Following Koch's postulates, the bacteria were confirmed to cause clinical symptoms such as damaged fins and mortality. Further studies on the pathogenicity of the bacteria are required since these bacteria can induce economic loss in other rainbow trout fisheries in Korea or other countries. Moreover, follow-up evaluation is required for this outbreak to control and prevent this disease.

Author Contributions: Conceptualization, W.J.J. and S.G.K.; Investigation, W.J.J.; Project administration, W.J.J., S.G.K. and S.C.P.; writing—original draft preparation, W.J.J.; writing-review and editing, S.G.K.; Software, W.J.J.; Visualization, S.G.K.; Formal analysis, W.T.O.; Funding acquisition, J.W.J.; Supervision, J.W.J. and S.C.P.; Validation, S.S.G., S.W.K., J.W.K., J.K., S.B.L., Y.M.L., C.C. and S.J.J. All authors have read and agreed to the published version of the manuscript.

Funding: This work was supported by the Basic Science Research Program through the National Research Foundation of Korea (NRF) funded by the Ministry of Education (2020R1A2C4001996).

Institutional Review Board Statement: Ethical review and approval were waived for this study as the Institutional Animal Care and Use Committee of Seoul National University does not provide an ethical number for research using fish except laboratory fish (e.g., zebrafish) which are grown under specific purpose for research in laboratory animal facilities. The fish that were used in this experiment were not an object under the committee guideline and explanation. Therefore, our research was performed in the Department of Aquaculture, Korea National College of Agriculture and Fisheries, where they have authorization from the government regarding fish cultivation and experiment. So, we followed strict ethical guidelines in experiment procedure and handling fish using the facility.

Conflicts of Interest: The authors declare no conflict of interest. 


\section{References}

1. Vandamme, P.; Bernardet, J.F.; Segers, P.; Kersters, K.; Holmes, B. New Perspectives in the Classification of the Flavobacteria: Description of Chryseobacterium gen. nov., Bergeyella gen. nov., and Empedobacter nom. rev. Int. J. Syst. Evol. 1994, 44, 827-831. [CrossRef]

2. García-López, M.; Meier-Kolthoff, J.P.; Tindall, B.J.; Gronow, S.; Woyke, T.; Kyrpides, N.C.; Göker, M. Analysis of 1000 type-strain genomes improves taxonomic classification of Bacteroidetes. Front. Microbiol. 2019, 10, 2083. [CrossRef]

3. del Carmen Montero-Calasanz, M.; Göker, M.; Rohde, M.; Spröer, C.; Schumann, P.; Busse, H.J.; Camacho, M. Chryseobacterium hispalense sp. nov., a plant-growth-promoting bacterium isolated from a rainwater pond in an olive plant nursery, and emended descriptions of Chryseobacterium defluvii, Chryseobacterium indologenes, Chryseobacterium wanjuense and Chryseobacterium gregarium. Int. J. Syst. Evol. 2013, 63, 4386-4395.

4. Kim, B.Y.; Weon, H.Y.; Cousin, S.; Yoo, S.H.; Kwon, S.W.; Go, S.J.; Stackebrandt, E. Flavobacterium daejeonense sp. nov. and Flavobacterium suncheonense sp. nov., isolated from greenhouse soils in Korea. Inst. J. Syst. Evol. 2006, 56, 1645-1649. [CrossRef]

5. Harrison, F.C. The discoloration of halibut. Can. J. Res. 1929, 1, 214-239. [CrossRef]

6. Ingrid Tsôeu, L.; Jooste, P.J.; Charimba, G.; Hugo, C.J. Spoilage potential of a novel group of bacteria isolated from dairy products. S. Afr. J. Sci. 2016, 112, 01-08.

7. Behrendt, U.; Ulrich, A.; Schumann, P. Chryseobacterium gregarium sp. nov., isolated from decaying plant material. Int. J. Syst. Evol. 2008, 58, 1069-1074. [CrossRef]

8. de Beer, H.; Hugo, C.J.; Jooste, P.J.; Willems, A.; Vancanneyt, M.; Coenye, T.; Vandamme, P.A. Chryseobacterium vrystaatense sp. nov., isolated from raw chicken in a chicken-processing plant. Int. J. Syst. Evol. 2005, 55, 2149-2153. [CrossRef]

9. Hantsis-Zacharov, E.; Shaked, T.; Senderovich, Y.; Halpern, M. Chryseobacterium oranimense sp. nov., a psychrotolerant, proteolytic and lipolytic bacterium isolated from raw cow's milk. Int. J. Syst. Evol. 2008, 58, 2635-2639. [CrossRef]

10. Chiu, C.H.; Waddingdon, M.; Greenberg, D.; Schreckenberger, P.C.; Carnahan, A.M. Atypical Chryseobacterium meningosepticum and meningitis and sepsis in newborns and the immunocompromised, Taiwan. Emerg. Infect. Dis. 2000, 6, 481. [CrossRef]

11. Bloch, K.C.; Nadarajah, R.; Jacobs, R. Chryseobacterium meningosepticum: An emerging pathogen among immunocompromised adults. Report of 6 cases and literature review. Medicine 1997, 76, 30-41. [CrossRef] [PubMed]

12. McKew, G. Severe sepsis due to Chryseobacterium indologenes in an immunocompetent adventure traveler. J. Clin. Microbiol. 2014, 52, 4100-4101. [CrossRef] [PubMed]

13. Michel, C.; Matte-Tailliez, O.; Kerouault, B.; Bernardet, J.F. Resistance pattern and assessment of phenicol agents' minimum inhibitory concentration in multiple drug resistant Chryseobacterium isolates from fish and aquatic habitats. J. Appl. Microbiol. 2005, 99, 323-332. [CrossRef] [PubMed]

14. Saticioglu, I.B.; Duman, M.; Altun, S. Genome analysis and antimicrobial resistance characteristics of Chryseobacterium aquaticum isolated from farmed salmonids. Aquaculture 2021, 535, 736364. [CrossRef]

15. Frank, J.A.; Reich, C.I.; Sharma, S.; Weisbaum, J.S.; Wilson, B.A.; Olsen, G.J. Critical evaluation of two primers commonly used for amplification of bacterial 16S rRNA genes. Appl. Environ. Microbiol. 2008, 74, 2461-2470. [CrossRef]

16. Kumar, S.; Stecher, G.; Li, M.; Knyaz, C.; Tamura, K. MEGA X: Molecular Evolutionary Genetics Analysis across computing platforms. Mol. Biol. Evol. 2018, 35, 1547-1549. [CrossRef]

17. Jung, W.J.; Kim, S.W.; Giri, S.S.; Kim, H.J.; Kim, S.G.; Kang, J.W.; Park, S.C. Janthinobacterium tructae sp. nov., Isolated from Kidney of Rainbow Trout (Oncorhynchus mykiss). Pathogens 2021, 10, 229. [CrossRef]

18. Saitou, N.; Nei, M. The neighbor-joining method: A new method for reconstructing phylogenetic trees. Mol. Biol. Evol. 1987, $4,406-425$.

19. Kimura, M. A simple method for estimating evolutionary rate of base substitutions through comparative studies of nucleotide sequences. J. Mol. Evol. 1980, 16, 111-120. [CrossRef]

20. Felsenstein, J. Confidence limits on phylogenies: An approach using the bootstrap. Evolution 1985, 39, 783-791. [CrossRef]

21. Wayne, P.A. Clinical and laboratory standards institute. Performance Standards for Antimicrobial Susceptibility Testing. 2011. Available online: https:/ /www.sid.ir/en/Journal/ViewPaper.aspx?ID=450165 (accessed on 23 December 2021).

22. Nematollahi, A.; Decostere, A.; Pasmans, F.; Haesebrouck, F. Flavobacterium psychrophilum infections in salmonid fish. J. Fish Dis 2003, 26, 563-574. [CrossRef] [PubMed]

23. Altinok, I. Multiplex PCR assay for detection of four major bacterial pathogens causing rainbow trout disease. Dis. Aquat. Org. 2011, 93, 199-206. [CrossRef] [PubMed]

24. Alonso, M.; Rodriguez, S.; Prieto, S.I.P. Nested PCR improves detection of infectious hematopoietic necrosis virus in cells coinfected with infectious pancreatic necrosis virus. J. Virol. Methods 1999, 81, 1-9. [CrossRef]

25. Garver, K.A.; Hawley, L.M.; McClure, C.A.; Schroeder, T.; Aldous, S.; Doig, F.; Richard, J. Development and validation of a reverse transcription quantitative PCR for universal detection of viral hemorrhagic septicemia virus. Dis. Aquat. Org. 2011, 95, 97-112. [CrossRef]

26. Inglis, $\mathrm{V}$;; Aoki, T. Rapid identification of Aeromonas salmonicida subspecies salmonicida by the polymerase chain reaction. Aquaculture 1996, 141, 13-24.

27. Cipriano, R.C. Aeromonas hydrophila and Motile Aeromonad Septicemias of Fish; US Department of the Interior, Fish and Wildlife Service, Division of Fishery Research: Washington, DC, USA, 1984; Volume 68. 
28. Scarpellini, M.; Franzetti, L.; Galli, A. Development of PCR assay to identify Pseudomonas fluorescens and its biotype. FEMS Microbiol. Lett. 2004, 236, 257-260. [CrossRef]

29. Barnes, M.E.; Brown, M.L. A review of Flavobacterium psychrophilum biology, clinical signs, and bacterial cold water disease prevention and treatment. Open Fish Sci. J. 2011, 4, 40. [CrossRef]

30. Loch, T.P.; Faisal, M. Emerging flavobacterial infections in fish: A review. J. Adv. Res. 2015, 6, 283-300. [CrossRef]

31. Fraser, S.L.; Jorgensen, J.H. Reappraisal of the antimicrobial susceptibilities of Chryseobacterium and Flavobacterium species and methods for reliable susceptibility testing. Antimicrob. Agents Chemother. 1997, 41, 2738-2741. [CrossRef]

32. Kim, S.G.; Giri, S.S.; Kim, S.W.; Kwon, J.; Lee, S.B.; Park, S.C. First Isolation and Characterization of Chryseobacterium cucumeris SKNUCL01, Isolated from Diseased Pond loach (Misgurnus anguillicaudatus) in Korea. Pathogens 2020, 9, 397. [CrossRef]

33. Sundell, K.; Landor, L.; Nicolas, P.; Jørgensen, J.; Castillo, D.; Middelboe, M.; Wiklund, T. Phenotypic and genetic predictors of pathogenicity and virulence in Flavobacterium psychrophilum. Front. Microbiol. 2019, 10, 1711. [CrossRef] [PubMed]

34. Karami, E.; Alishahi, M.; Molayemraftar, T.; Ghorbanpour, M.; Tabandeh, M.R.; Mohammadian, T. Study of pathogenicity and severity of Lactococcus garvieae isolated from rainbow trout (Oncorhynchus mykiss) farms in Kohkilooieh and Boyerahmad province. Fish. Aquat. Sci. 2019, 22, 1-7. [CrossRef]

35. Pridgeon, J.W.; Klesius, P.H.; Garcia, J.C. Identification and virulence of Chryseobacterium indologenes isolated from diseased yellow perch (Perca flavescens). J. Appl. Microbiol. 2013, 114, 636-643. [CrossRef] [PubMed]

36. Shahi, N.; Sharma, P.; Pandey, J.; Bisht, I.; Mallik, S.K. Characterization and pathogenicity study of Chryseobacterium scophthalmum recovered from gill lesions of diseased golden mahseer, Tor putitora (Hamilton, 1822) in India. Aquaculture 2018, 485, 81-92. [CrossRef]

37. Oh, W.T.; Jun, J.W.; Giri, S.S.; Yun, S.; Kim, H.J.; Kim, S.G.; Kim, S.W.; Han, S.J.; Kwon, J.; Park, S.C. Isolation of Chryseobacterium siluri sp. nov., from liver of diseased catfish (Silurus asotus). Heliyon 2020, 6, e03454. [CrossRef] 